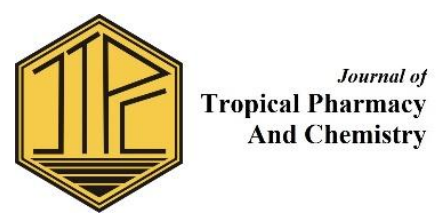

\title{
UJI AKTIVITAS TRAKEOSPASMOLITIK EKSTRAK ETANOL CENTELLA ASIATICA (L.) URB. PADA ORGAN TERPISAH TRAKEA MARMUT UNTUK MELIHAT EFEK ANTIASMA
}

\author{
Emil Bachtiar Moerad*, Swandari Paramita, Abdillah Iskandar, Sjarif Ismail, \\ Moriko Pratiningrum, Hadi Irawiraman \\ Fakultas Kedokteran Universitas Mulawarman, Samarinda \\ *Corresponding Author: emilpsku@yahoo.co.id
}

\begin{abstract}
Asthma is a chronic inflammatory airway disease characterized by the occurrence of reversible hyperesponsif and constriction of the airways. Asthma is still a major health problem in the world. The provision of anti-asthma drugs is treatment of the disease. However, there are problems of drug side effects and problems costs incurred to purchase the drug, especially asthma is a chronic disease that requires longterm treatment. Thus it is necessary for natural based antiasthma drug development with affordable cost and fewer side effects. This study was conducted to test the potential of the ethanol extract of Centella asiatica (L.) Urb. which is traditionally used by Dayak tribe as cough medicine. This study was conducted to look at the tracheospasmolytics activity of the ethanol extract of $C$. asiatica on isolated organ of guinea pig trachea to see the effect of antiasthma. The results showed the extract of $C$. asiatica had significant tracheospasmolytics activity when compared to the negative control. Although the vE max value of $C$. asiatica lower than aminophylline, but the $E C_{50}$ value is not much different from the aminophylline as a positive control. It is concluded that the ethanol extract of $C$. asiatica had the tracheospasmolytics effect based activity for antiasthma.
\end{abstract}

Keywords: Centella asiatica, spasmolytic, trachea isolated organ

\begin{abstract}
ABSTRAK
Asma merupakan penyakit inflamasi kronik saluran nafas yang ditandai dengan terjadinya hiperesponsif saluran nafas dan penyempitan saluran nafas secara reversibel. Asma hingga kini masih merupakan masalah kesehatan utama di dunia. Pemberian obat-obatan anti asma merupakan penatalaksanaan penyakit tersebut. Namun demikian terdapat masalah efek samping obat dan masalah biaya yang dikeluarkan untuk pembelian obat tersebut, apalagi asma merupakan penyakit kronis yang memerlukan pengobatan jangka panjang. Dengan demikian maka perlu pengembangan obat antiasma berbasis tumbuhan obat dengan biaya yang lebih terjangkau dan efek samping yang lebih sedikit. Penelitian ini dilakukan untuk menguji potensi ekstrak etanol Centella asiatica (L.) Urb. yang secara tradisional digunakan etnis Dayak sebagai obat batuk. Penelitian ini dilakukan untuk melihat aktivitas trakeospasmolitik ekstrak etanol $C$. asiatica pada organ terpisah trakea marmut untuk melihat efek antiasma. Hasil penelitian menunjukkan ekstrak $C$. asiatica memiliki aktivitas trakeospasmolitik yang signifikan jika dibandingkan dengan kontrol negatif. Meskipun nilai E maks $C$. asiatica lebih rendah daripada aminofilin, namun nilai $\mathrm{EC}_{50}$ tidak jauh berbeda dengan aminofilin sebagai kontrol positif. Kesimpulan penelitian ini adalah ekstrak etanol $C$. asiatica memiliki efek antiasma berdasarkan aktivitas trakeospasmolitiknya.
\end{abstract}

Kata kunci: Centella asiatica, spasmolitik, organ terpisah trakea

Submitted on: 10 April 2017

Accepted on: 8 December 2017

DOI: https://doi.org/10.25026/jtpc.v4i2.139 


\section{PENDAHULUAN}

Asma merupakan penyakit inflamasi kronik saluran nafas yang ditandai dengan terjadinya hiperesponsif saluran nafas dan penyempitan saluran nafas secara reversibel [1]. Asma adalah salah satu penyakit tidak menular utama di dunia. Sekitar 235 juta penduduk di seluruh dunia menderita asma, terutama pada anak-anak. Faktor risiko utama untuk terjadinya asma adalah kombinasi dari kerentanan genetik dengan paparan lingkungan seperti polusi udara [2].

Obat-obatan asma diberikan untuk penatalaksanaan penderita asma. Obatobatan asma ada beberapa macam, yaitu golongan beta agonis kerja singkat seperti salbutamol; golongan antikolinergik seperti ipratropium bromida; dan golongan agonis adrenergik seperti epinefrin. Sementara itu untuk penatalaksanaan asma yang jangka panjang digunakan golongan kortikosteroid; golongan beta adrenoseptor agonis kerja lama seperti salmeterol; golongan antagonis reseptor leukotrin seperti zafirlukast; dan golongan stabiliser sel mast seperti sodium kromolin [3].

Hampir sebagian besar obat-obatan asma tersebut diatas memiliki efek samping terhadap pasien. Selain itu biaya yang dikeluarkan untuk pembelian obatobatan tersebut tidak murah, apalagi untuk pengobatan asma yang bersifat jangka panjang. Berdasarkan hal tersebut, maka upaya pencarian obat antiasma baru perlu dilakukan. Salah satu sumber obat antiasma adalah tumbuhan obat yang berasal dari alam, yang diharapkan lebih murah dan lebih sedikit efek sampingnya. Penelitian terhadap pengobatan tradisional pada masyarakat di berbagai tempat menunjukkan adanya tumbuhan yang digunakan untuk menghilangkan sesak nafas. Penelitian juga menunjukkan bahwa beberapa tumbuhan obat memiliki efek mengurangi kekakuan otot polos. Hal ini menunjukkan adanya potensi tumbuhan obat sebagai spasmolitik [4]. Mekanisme pengurangan kekakuan otot polos ini menyerupai mekanisme pada obat-obatan asma, terutama pada golongan antikolinergik.

Salah satu tumbuhan obat yang diduga memiliki potensi efek spasmolitik adalah Centella asiatica (L.) Urb. Tumbuhan ini tersebar di Afrika, Australia, Amerika Selatan hingga Asia Selatan dan Tenggara, termasuk Indonesia. Tumbuhan ini dikenal dengan nama pegagan dalam bahasa Indonesia dan asiatic atau indian pennywort dalam bahasa Inggris [5]. Sementara itu etnis Dayak di Kalimantan Utara menyebutnya sebagai daun tapal kuda dan digunakan untuk mengobati sakit batuk [6]. Keluhan batuk dalam penelitian ini diidentikkan dengan asma, karena salah satu manifestasi klinik awal penderita asma adalah batuk, sedangkan sesak masih belum ada, hal ini sulit dibedakan oleh orang awam dan pengobat tradisional. Berdasarkan hal tersebut diatas maka penelitian ini bermaksud untuk melihat aktivitas spasmolitik dan antispasmodik ekstrak $C$. asiatica dengan menggunakan organ terpisah trakea marmut untuk melihat efek antiasma.

\section{METODE PENELITIAN}

\section{Waktu dan Tempat}

Penelitian dilakukan pada bulan Mei hingga Oktober 2016. Penelitian ini telah memperoleh kelayakan etik dari Komisi Etik Penelitian Kedokteran dan Kesehatan, Fakultas Kedokteran Universitas Mulawarman. Lokasi pengambilan sampel tumbuhan obat dilakukan di Kabupaten Malinau, Kalimantan Utara. Identifikasi tumbuhan obat dilakukan oleh Laboratorium Dendrologi, Fakultas Kehutanan 
Universitas Mulawarman. Pengolahan sampel tumbuhan obat hingga proses ekstraksi dan uji aktivitas trakeospasmolitik dengan organ terpisah trakea marmut dilakukan di Laboratorium Farmakologi, Fakultas Kedokteran Universitas Mulawarman.

\section{Pembuatan Ekstrak Tumbuhan Obat}

Simplisia yang telah dihaluskan lalu dimaserasi dengan pelarut etanol. Pada penelitian ini digunakan pelarut etanol absolut. Untuk pembuatan ekstrak, dimasukkan satu bagian serbuk kering simplisia ke dalam maserator (ditimbang botol maserasi sebelum dimasukkan simplisia dan ditimbang ulang setelah dimasukkan simplisia), ditambahkan 10 bagian pelarut (ukur volume sebelum dimasukkan). Selanjutnya direndam selama 6 jam sambil sesekali diaduk (menggunakan shaker orbital dengan kecepatan 20 rpm selama 10 menit) pada suhu kamar, kemudian didiamkan selama 18 jam. Maserat dipisahkan dengan cara filtrasi dengan menggunakan kertas saring Whatman. Proses penyarian diulangi dua kali dengan jenis dan jumlah pelarut yang sama. Semua maserat dikumpulkan, kemudian diuapkan dengan vakum rotavapor suhu $50^{\circ} \mathrm{C}$ hingga diperoleh ekstrak kental. Ekstrak pekat yang didapat kemudian dikeringkan lebih lanjut dengan dimasukkan dalam desikator yang berisi silika gel biru dalam oven suhu $50^{\circ} \mathrm{C}$. Setelah didapatkan ekstrak kering, dihitung rendemen yang diperoleh, yaitu persentase bobot $(\mathrm{b} / \mathrm{b})$ antara rendemen dengan bobot serbuk simplisia yang digunakan dengan cara penimbangan. Ekstrak kering disimpan dalam kulkas $-20^{\circ} \mathrm{C}$ sebelum dilakukan penelitian lebih lanjut [7].

\section{Uji Aktivitas Tracheospasmolitik Saluran Nafas}

Untuk melihat aktivitas trakheospasmolitik bahan ekstrak secara in vitro, dilakukan pada organ terpisah trakhea marmut yang diprekontraksi dengan histamin. Pengulangan dilakukan sebanyak 3 kali dan setiap pengujian digunakan satu marmut untuk satu organ terpisah trakhea mamut.

Untuk mendapatkan organ terpisah trakhea marmut, maka dilakukan euthanasia dengan penyuntikan ketamin secara intraperitoneal dengan dosis 100 $\mathrm{mg} / \mathrm{kgBB}$; setelah marmut tidak bergerak, dilakukan dislokasi pada leher. Cara pengambilan trakhea dan preparasi serta cara pemasangan organ terpisah cincin trakea dilakukan seperti yang dijelaskan oleh Vogel dan Vogel (1997) [8]. Trakea yang telah dipotong sekitar 3-4 mm dimasukkan dalam organ bath yang berisi Physiological Salt Solution (PSS), salah satu ujung trakea dipasang transducer isometrik yang dihubungkan dengan alat amplifikasi perekam digital $A D$ instrument dengan program Chart ver.5. Perubahan tonus kontraksi otot trakea pada komputer tercatat dalam gram. Trakea dibiarkan dalam organ bath untuk ekuilibrasi selama 60 menit dalam larutan PSS yang diganti setiap 10 menit dengan PSS yang baru.

Setelah stabil, maka diberikan histamin untuk melihat respons kontraksi otot trakea yang meningkat sampai maksimal mendatar, selanjutnya diberikan isoproterenol untuk melihat respons trakheospasmolitik. Jika terjadi peningkatan tonus setelah pemberian histamin dan penurunan tonus setelah pemberian isoproterenol, maka trakhea tersebut dinyatakan baik dan siap untuk dilakukan bioassay ekstrak. Selanjutnya larutan diganti tiga kali berturut-turut dan setiap 10 menit sekali larutan diganti 
dengan yang baru sampai keadaan stabil dan siap untuk dilakukan percobaan.

Pertama-tama dilakukan pemberian histamin satu konsentrasi dan diamati sampai mencapai kontraksi trakhea yang maksimal dan mendatar, lalu diberikan ekstrak antiasma secara etnobotani secara kumulatif $(0,01 ; 0,03 ; 0,1 ; 0,3$ dan 3 $\mathrm{mg} / \mathrm{ml}$ ) sampai efek maksimal tercapai. Dari hasil uji ekstrak tersebut dapat diketahui nilai E maks ekstrak. Hasil yang didapat dinyatakan dalam persen penurunan tonus yang dihitung dari: [nilai tonus maksimum trakhea setelah pemberian dosis tunggal histamin dikurang penurunan tonus maksimum trakhea setelah pemberian bahan ekstrak] dibagi nilai tonus maksimum setelah pemberian dosis tunggal histamin kemudian dikali $100 \%$. Penghitungan ini dilakukan pada setiap dosis ekstrak yang diberikan sehingga dapat ditabulasikan dalam bentuk kurva dosis respon, selanjutnya dihitung nilai $\mathrm{EC}_{50}$.

\section{Analisis Data}

Aktivitas trakheospasmolitik ditabulasikan dalam bentuk mean $\pm \mathrm{SE}$ kurva dosis respon, kemudian dihitung nilai $\mathrm{E}$ maks dan $\mathrm{EC}_{50}$. Data diuji homogenitas dan variansi, jika distribusi data normal dan variansi sama dilanjutkan dengan uji t. Perbedaan dikatakan signifikan jika $\mathrm{p}<0.05$.

\section{HASIL DAN PEMBAHASAN}

Hasil uji aktivitas spasmolitik ekstrak etanol daun $C$. asiatica pada organ terpisah trakea marmut pada konsentrasi $0,01,0,03,0,1,0,3,1$ dan 3 $\mathrm{mg} / \mathrm{ml}$ secara berurutan adalah sebagai berikut: $\quad(1,27 \pm 0,81), \quad(0,28 \pm 0,24)$, $(-1,22 \pm 0,74),(-2,67 \pm 0,85),(-4,84 \pm 1,42)$, $(-9,22 \pm 1,39) \%$; dan pada Kontrol (pelarut ekstrak) didapatkan hasil $(2,31 \pm 0,61)$, $(3,68 \pm 0,42), \quad(5,54 \pm 0,97), \quad(6,00 \pm 0,47)$, $(5,85 \pm 0,57), \quad(4,80 \pm 0,86) \%$; sedangkan pada aminofilin didapatkan hasil $(0,82 \pm 1,01), \quad(0,68 \pm 1,32), \quad(-3,94 \pm 3,19)$, $(-23,78 \pm 5,53), \quad(-57,78 \pm 5,14)$, $(-93,68 \pm 3,01) \%$; hasil uji statistik antara kelompok Kontrol dengan ekstrak dan Kelompok aminofilin dengan ekstrak dapat dilihat pada Gambar 1. Hasil penelitian menunjukkan aktivitas spasmolitik ekstrak etanol daun $C$. asiatica pada konsentrasi $3 \mathrm{mg} / \mathrm{ml}$ mampu menurunkan tonus ileum marmut lebih baik dibanding dengan kontrol negatif dan secara statistik ada perbedaan bermakna antara keduanya $(\mathrm{p}<0,05)$.

Efek maksimal (E maks) ekstrak etanol daun $C$. asiatica lebih tinggi daripada aminofilin sebagai kontrol positif. Hal ini menunjukkan kekuatan ekstrak tumbuhan obat ini memang tidak sekuat aminofilin, seperti yang terlihat pada Gambar 2. Namun demikian untuk $\mathrm{EC}_{50}$, ekstrak etanol daun $C$. asiatica memiliki nilai yang tidak jauh berbeda dengan aminofilin sebagai kontrol positif, seperti yang terlihat pada Gambar 3. Hal ini menunjukkan bahwa $C$. asiatica memiliki efikasi yang baik (dengan konsentrasi yang kurang lebih sama dengan aminofilin, sudah dapat menimbulkan efek 50\%) sebagai spasmolitik jika dibandingkan dengan aminofilin. Efikasi berhubungan dengan E maks dan potensi suatu obat berhubungan dengan niai $\mathrm{EC}_{50}$ [9]. 
Uji aktivitas trakeospasmolitik ekstrak etanol centella asiatica (l.) Urb. Pada organ terpisah trakea marmut untuk melihat efek antiasma

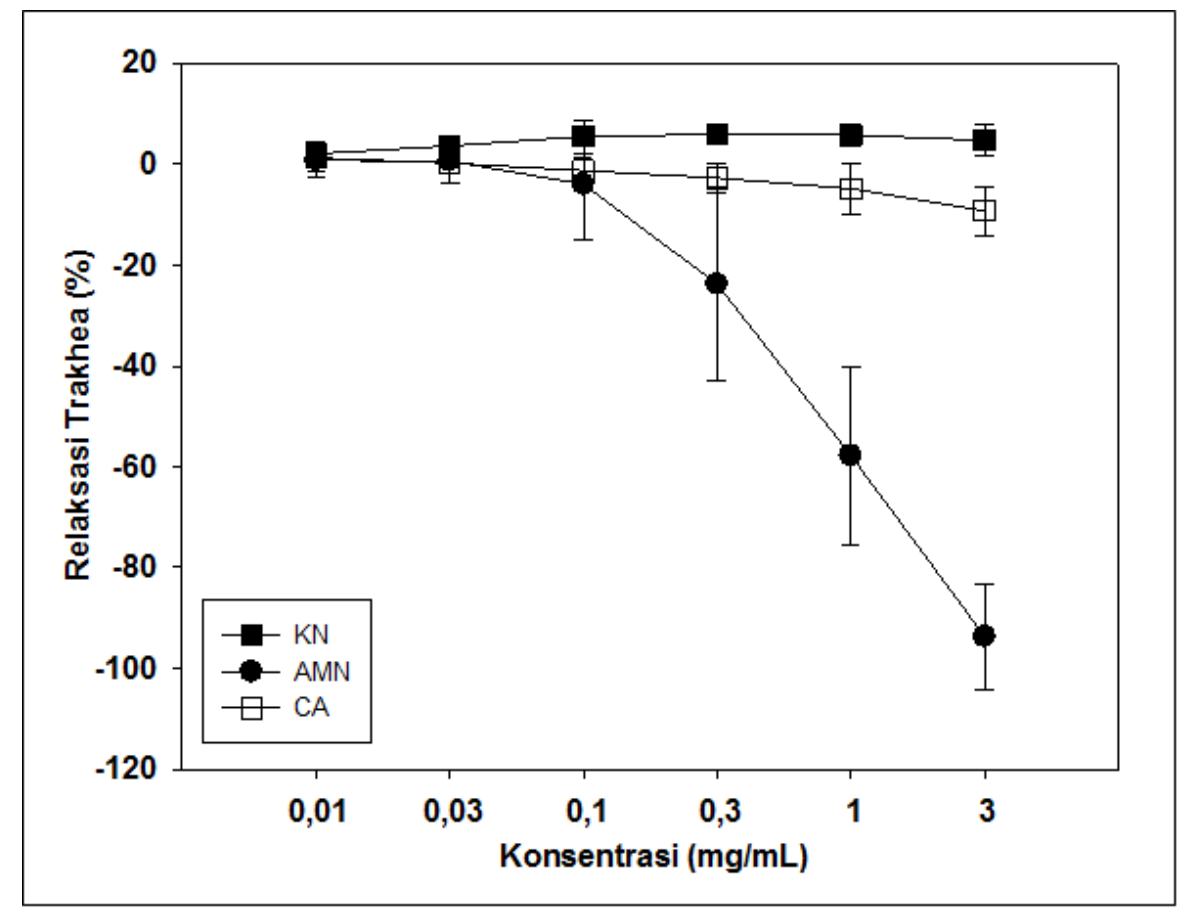

Gambar 1. Grafik perbedaan relaksasi trakea marmut antara C. asiatica (CA), aminofilin sebagai kontrol positif $(A M N)$ dan kontrol negatif $(K N)$ pada isolat organ trakea marmut

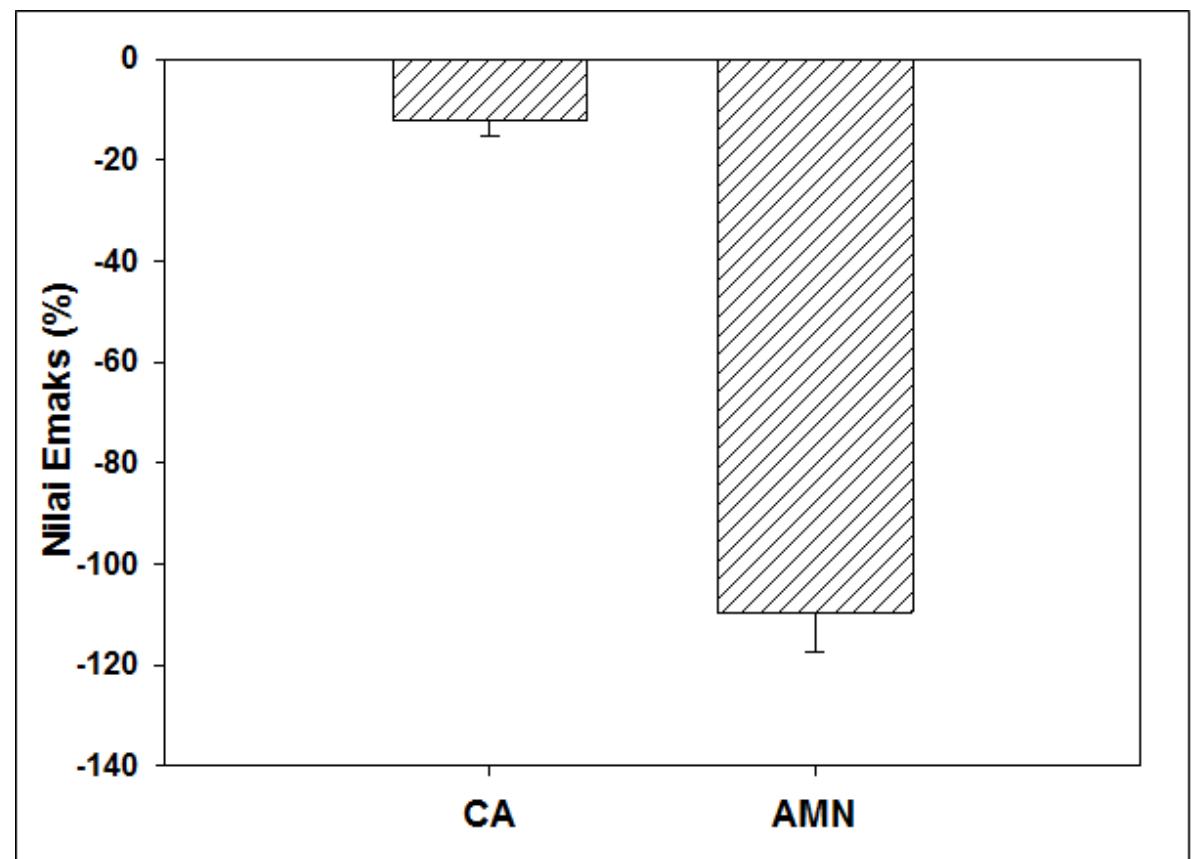

Gambar 2. Grafik perbandingan nilai E maks antara ekstrak C. asiatica (CA) dan aminofilin sebagai kontrol positif (AMN) 


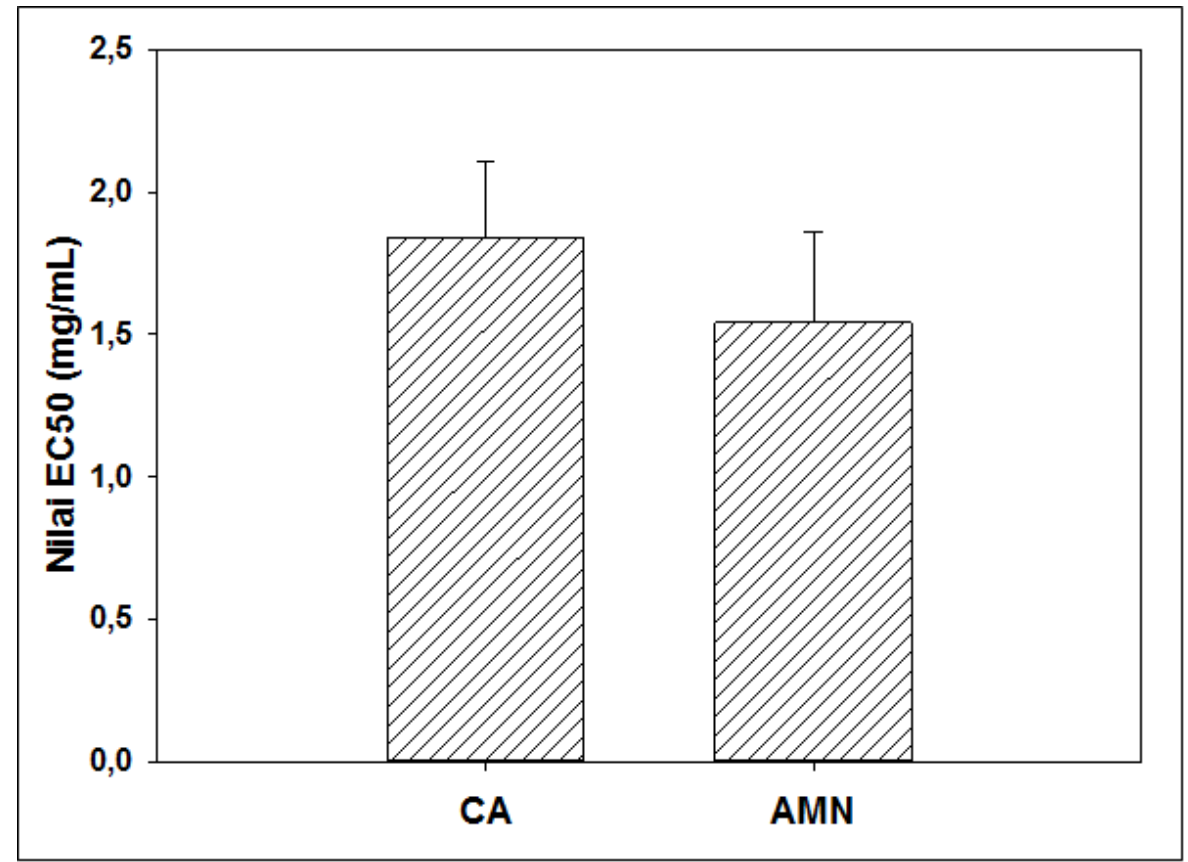

Gambar 3. Grafik perbandingan $E_{50}$ antara antara ekstrak C. asiatica (CA) dan aminofilin sebagai kontrol positif $(A M N)$

C. asiatica termasuk dalam famili Apiaceae. Sinonim tumbuhan ini adalah Centella asiatica var. asiatica, Centella asiatica var. crista Makino, Centella boninensis Nakai ex Tuyama, Centella glochidiata (Benth.) Drude, Centella hirtella Nannf., Centella tussilaginifolia (Baker) Domin, Centella ulugurensis (Engl.) Domin, Centella uniflora (Colenso) Nannf., Chondrocarpus asiaticus Nutt., Chondrocarpus triflorus Nutt., Glyceria asiatica Nutt., Glyceria triflora Nutt., Hydrocotyle asiatica L., Hydrocotyle asiatica var. floridana J.M.Coult. \& Rose, Hydrocotyle asiatica var. monantha F.Muell., Hydrocotyle biflora P. Vell., Hydrocotyle brasiliensis Scheidw. ex Otto \& F. Dietr., Hydrocotyle brevipedata St. Lager \& St.Lag., Hydrocotyle dentata A.Rich, Hydrocotyle ficarifolia Stokes, Hydrocotyle ficariodes Lam., Hydrocotyle hebecarpa DC., Hydrocotyle inaequipes DC., Hydrocotyle lunata Lam., Hydrocotyle lurida Hance, Hydrocotyle nummularioides A. Rich., Hydrocotyle pallida DC., Hydrocotyle reniformis Walter, Hydrocotyle repanda Pers., Hydrocotyle sarmentosa Salisb., Hydrocotyle thunbergiana Spreng., Hydrocotyle triflora Ruiz \& Pav., Hydrocotyle tussilaginifolia Baker, Hydrocotyle uniflora Colenso, Hydrocotyle wightiana Wall., dan Trisanthus cochinchinensis Lour [10].

Penelitian yang menemukan zat aktif yang terkandung di dalam ekstrak $C$. asiatica telah banyak dilakukan. Derivat utama triterpen saponosid yang ditemukan dalam $C$. asiatica adalah asiatic acid, madecassic acid, asiaticoside dan madecassoside [11]. Asiaticoside berhasil diisolasi pertama kali dari daun C. asiatica pada tahun 1950an. Asiaticoside selanjutnya menjadi sumber pembuatan asiatic acid. Asiacotide sendiri awalnya menunjukkan efek antimikroba, dan saat ini digunakan sebagai bahan herbal penyembuhan luka bersama dengan madecassic acid dan 
asiatic acid. Madecassic acid sendiri juga memiliki kemampuan menstimulasi sintesis kolagen [12]. Sepanjang pengetahuan peneliti, ini adalah studi pertama yang meneliti tentang efek trakeospasmolitik dari ekstrak etanol daun $C$. asiatica. Meskipun demikian tumbuhan ini tercatat di beberapa tempat memang digunakan secara tradisional sebagai obat asma [13,14]. Penelitian serupa dilakukan oleh Jamil et al (2007) yang menunjukkan bahwa ekstrak etanol C. asiatica menunjukkan aktivitas antispasmodik pada kontraksi ileum tikus yang diinduksi asetilkolin, yang disebabkan oleh kandungan glikosidanya [15].

Komponen bioaktif yang diisolasi dari $C$. asiatica seperti quarcetin memiliki efek antiasma dan perelaksasi otot polos, apigenin memiliki efek antispasmodik pada otot polos dan luteolin memiliki efek antispasmodik [16].

\section{KESIMPULAN}

Hasil penelitian ini menunjukkan bahwa ekstrak etanol $C$. asiatica memiliki efek antiasma berdasarkan aktivitas trakeospasmolitiknya Perlu adanya penelitian lanjutan agar $C$. asiatica dapat dikembangkan sebagai sumber obat antiasma baru berbasis tumbuhan obat.

\section{DAFTAR PUSTAKA}

[1]. Kasper DL, Hauser SL, Jameson JL, Fauci AS, Longo DL, Loscalzo J. (2015). Harrison's Principles of Internal Medicine. Nineteenth Edition. 1669-1680. McGraw Hill Education. New York.

[2]. World Health Organization. (2013). Factsheets: Asthma. http://www.who.int/mediacentre/fa ctsheets/fs307/en/. Diakses tanggal 29 Maret 2017.
[3]. Papadakis MA, McPhee SJ. (2013). Current Medical Diagnosis and Treatment. Fifty Second Edition. 243-259. McGraw Hill Lange. New York.

[4]. Amit K, Vandana V. (2013). Medicinal properties of Acorus calamus. Journal of Drug Delivery \& Therapeutics. 3(3): 143144.

[5]. World Health Organization. (1999). WHO Monographs On Selected Medicinal Plants. Volume 1. 77-85. World Health Organization. Geneva.

[6]. Ismail S, Suwasono RA, Supriyoko W, Kuswanto H, Paryono P. (2015). Laporan Penelitian Riset Eksplorasi Pengetahuan Lokal Etnomedisin dan Tumbuhan Obat di Indonesia Berbasis Komunitas di Suku Abai, Kabupaten Malinau, Propinsi Kalimantan Utara. Badan Penelitian dan Pengembangan Kesehatan. Kementerian Kesehatan RI.

[7]. Departemen Kesehatan RI. (2008). Farmakope Herbal Indonesia. Edisi Pertama. Departemen Kesehatan RI. Jakarta.

[8]. Vogel HG, Vogel WH. (1997). Drug discovery and evaluation: pharmacological assays. Chapter D: Respiratory activity: Spasmolytic activity in isolated guinea pig trachea. 184-185. Springer-Verlag. Berlin.

[9]. Katzung BG. (2009). Basic and Clinical Pharmacology. Eleventh Edition. McGraw Hill. San Fransisco.

[10]. The Plant List. (2013). Version 1.1. http://www.theplantlist.org

[11]. Orhan IE. (2012). Centella asiatica (L.) Urban: From Traditional Medicine to Modern Medicine with Neuroprotective Potential. Evidence-Based Complementary and Alternative Medicine. ID 946259: 1-8.

[12]. Alfarra HY, Omar MN. (2013). Centella asiatica: from folk remedy to the medicinal biotechnology - a state revision. International Journal of Biosciences. 3(6): 49-67.

[13]. Bhavna D, Jyoti K. (2011). Centella asiatica: the elixir of life. International Journal of Research in Ayurveda and Pharmacy. 2(2): 431-438.

[14]. Chippada SC, Volluri SS, Bammidi SR, Vangalapati M. (2011). In Vitro Anti Inflammatory Activity of Methanolic Extract Of Centella asiatica BY HRBC Membrane Stabilization. Rasayan Journal of Chemistry. 4(2): 457-460. 
Uji aktivitas trakeospasmolitik ekstrak etanol centella asiatica (l.) Urb. Pada organ terpisah trakea marmut untuk melihat efek antiasma

[15]. Jamil SS, Nizami Q, Salam M. (2007). Centella asiatica (Linn.) Urban A Review. Natural Product Radiance. 6(2): 158-170.
[16]. Roy DC, Barman SK, Shaik MM. (2013).

Current Updates on Centella asiatica: Phytochemistry, Pharmacology and Traditional Uses. Medicinal Plant Research. 3(4): 20-36

How to cited this article :

Moerad EB, Paramita S, Iskandar A, Ismail S, Pratiningrum M, Irawiraman H. 2017. Uji Aktivitas Trakeospasmolitik Ekstrak Etanol Centella asiatica (1.) Urb. pada Organ Terpisah Trakea Marmut untuk Melihat Efek Antiasmanorvegicus, J. Trop. Pharm. Chem. (4)2. 52-58. 